\title{
PARTISIPASI POLITIK MASYARAKAT DALAM PEMUNGUTAN SUARA PEMILIHAN BUPATI DAN WAKIL BUPATI SINTANG TAHUN 2020 DALAM KONDISI BENCANA NON ALAM CARONA VIRUS DISEASE 2019 (COVID-19)
}

\author{
A.M. YADISAR \\ Fakultas Ilmu Sosial dan Ilmu Politik Universitas Kapuas Sintang \\ Email: yadisar75@gmail.com
}

\begin{abstract}
Abstak: Di Indonesia perjalanan demokrasi sudah banyak mengalami kemajuan dan kepercayaan rakyat pada elit politik menjadikan proses rekrutmen mengarah pada demokrasi langsung, termasuk pemilihan kepala daerah. Pemilihan Bupati dan Wakil Bupati secara langsung merupakan fenomena kenegaraan baru di Indonesia dengan sistem pelaksanaan Pemilihan Bupati dan Wakil Bupati Serentak sehingga segala hal yang melandasinya perlu dibahas dengan seksama. Dalam hal ini kita perlu memperhatikan hubungan negara dan rakyat dalam bingkai demokrasi lokal, asas desentralisasi dan partisipasi politik masyarakat. Kabupaten Sintang merupakan salah satu kabupaten yang ikut dalam pelaksanaan pesta demokrasi pada tahun 2020. Pelaksanaan pemilihan Bupati dan Wakil Bupati Sintang sudah berjalan sesuai dengan yang direncanakan mulai dari tahap persiapan sampai pada tahap penyelenggaraan mengacu kepada PKPU Nomor 6 Tahun 2020, dirubah dengan PKPU Nomor 10 Tahun 2020 dan Perubahan Kedua PKPU Nomor 13 Tahun 2020 tentang Pelaksanaan Pemilihan Gubernur dan Wakil Gubernur, Bupati dan Wakil Bupati, dan/atau Wali Kota dan Wakil Wali Kota Serentak Lanjutan dalam Kondisi Bencana Alam Covid-19. Pelaksanaan pemungutan suara dilaksanakan pada tanggal 9 Desember 2020 secara serentak di seluruh Kecamatan di Kabupaten Sintang, Partisipasi politik masyarakat dalam pemilihan Bupati dan Wakil Bupati Sintang sebesar 82,75\% dari jumlah pemilih. Faktor-Faktor yang mempengaruhi partisipasi politik masyarakat adalah perangsang politik, karakteristik pribadi, karekteristik sosial dan keadaan politik.
\end{abstract}

Kata Kunci : Partisipasi Politik, Pemungutan Suara, Pemilihan

Pemilihan Umum merupakan salah satu sarana demokrasi, dimana demokrasi menjadi sarana pula untuk menyejahterakan masyarakat. Indonesia menjadi salah satu negara demokrasi terbaik di dunia pasca reformasi 1998. Hal itu diakaui dunia karena pelaksanaan pemilu di Indonesia berlangsung dengan aman dan demokratis, tanpa ada kendala berarti.

Salah satu indikator matangnya demokrasi suatu bangsa adalah tingginya tingkat partisipasi politik masyarakatnya. Dalam konteks ini partisipasi yang diinginkan adalah proses transformasi kepentingan publik dalam ranah struktur politik, dipilih dan memilih sesungguhnya merupakan posisi yang sama, yakni berpartisipasi dalam dunia politik. Ketika masyarakat aktif dalam ranah politik, mereka mengatakan inilah bagian dari partisipasi dalam sistem politik.

Agenda ke depan bangsa ini tidak bisa lepas dari upaya penguatan, partisipasi dan kemandirian rakyat lewat proses-proses yang demokratik. Catatan ini penting mengingat karakter dan kamampuan berdemokrasi rakyat masih sangat lemah, sementara secara faktual, rakyat sebenamya hidup di ruang yang sangat terbuka. Persoalan mendasar adalah rakyat hidup di tengah demokratisasi yang mulai terbuka lebar pasca lengsernya rezim orde baru yang kemudian diiringi oleh kebebasan partisipasi yang luar biasa, akan tetapi belum diiringi oleh kematangan mental dan sikap dalam berdemokrasi. Kebebasan berpolitik, tidak ditopang oleh rasionalitas, daya kritis, dan kemandirian berpikir dan bersikap. Padahal nilai utama yang diusung oleh demokrasi adalah terbukanya ruang-ruang politik rasional dalam diri setiap rakyat. Kebebasan yang tidak didasari oleh rasionalitas politik akhir-akhir ini sangat nampak dalam upaya penguatan kekuasaan pada aras politik lokal. Peluang konflik politik dalam perebutan kekuasaan akan meningkat seiring ditetapkannya mekanisme Pemilihan Kepala Daerah (Pilkada) secara langsung serentak. Di tengah belum menguatnya kesadaran poitik di level grass root, maka momentum Pilkada menjadi pertarungan politik yang selalu membuka ruang potensi konflik, manipulasi, money politics, dan intimidasi. 
Sistem pemilu kepala daerah secara langsung lebih menjanjikan dibandingkan sistem yang berlaku sebelumnya. Pilkada langsung memiliki kapasitas yang memadai untuk memperluas partisipasi politik masyarakat. Sehingga masyarakat daerah memiliki kesempatan memilih secara bebas pemimpinya tanpa suatu tekanan atau intimidasi, floating mass (masa mengambang), kekerasan politik, maupun penekanan jalur birokrasi. Dapat dikatakan pilkada merupakan momentum yang cukup tepat munculnya berbagai varian preferensi pemilih yang menjadi faktor dominan dalam melakukan tindakan atau perilaku politiknya.

Bangsa Indonesia sejak maret 2020 dihadapkan dengan kondisi Bencana Alam Non Alam Carona Virus Disease 2019 (COVID 19), yang mengharuskan penyelenggara pemilu melakukan perubahan dan penyesuaian regulasi berkaitan dengan pelaksanaan pemilihan kepala daerah yaitu peraturan Komisi Pemilihan Umum Nomor 6 Tahun 2020, dirubah dengan Peraturan Komisi Pemilihan Umum Nomor 10 Tahun 2020 dan dirubah kembali dengan Peraturan Komisi Pemilihan Umum Nomor 13 Tahun 2020 Tentang Pelaksanaan Pemilihan Gubernur dan Wakil Gubernur, Bupati dan Wakil Bupati, dan/atau Wali Kota dan Wakil Wali Kota Serentak Lanjutan Dalam Kondisi Bencana Non Alam Corona Virus Disease 2019 (COVID 19). Kondisi ini bisa menyebabkan partisipasi politik masyarakat dalam pemilihan kepala daerah mengalami penurunan, yang berarti tingkat Golput mengalami peningkatan.

Hal tersebut merupakan salah satu tantangan dalam pemilu yaitu kecenderungan maraknya praktek politik uang (money politics) yang berlangsung hampir di seluruh tingkatan pemilihan umum. Ari Dwipayana (2009) menyebutkan bahwa politik uang adalah salah satu faktor penyebab demokrasi berbiaya tinggi. Sedangkan Wahyudi Kumotomo (2009) menyatakan bahwa setiap orang tahu bahwa kasuskasus politik uang merupakan hal yang jamak dalam pemilu setelah reformasi. Kendatipun semua calon jika ditanya akan selalu mengatakan bahwa mereka tidak terlibat dalam politik uang, warga akan segera bisa menunjuk bagaimana para calon itu menggunakan uang untuk "membeli suara" di daerah pemilihan mereka. Menurut Daniel Dhakidae (2011) politik uang ini merupakan mata rantai dari terbentuknya kartel politik. Demokrasi perwakilan yang mengandalkan votes (suara) dengan mudah diubah menjadi sebuah komoditas, yang akan dijual pada saat sudah diperoleh dan dibeli saat belum diperoleh. Dibeli waktu pemilihan umum dengan segala teknik dan dijual pula dengan segala teknik.

Dalam konteks penguatan demokratisasi, pilkada langsung sebenarnya berpeluang untuk melakukan pematangan dan penyadaran berdemokrasi. Rakyat yang memiliki kesadaran berdemokrasi adalah langkah awal dalam menuju lajur demokrasi yang benar. Sebagaimana disampaikan Murray Print (1999), pembentukan warga negara yang memiliki keadaban demokratis dan demokrasi keadaban paling mungkin dilakukan secara efektif hanya melalui pendidikan kewarganegaraan (civic education). Aktualisasi dan civic education sebenarnya terletak kepada tingkat partipasi poitik rakyat di setiap momentum politik seperti pemilu. Partisipasi politik yang lemah berakibat pada sebuah realitas politik yang kini menggejala di permukam dan terkait dengan, era otonomi daerah yaitu terjadinya kesenjangan politik antara masyarakat sipil dengan lembaga kekuasaan lokal, di mana aktor pelaksana kekuasaan lokal (baik unsur birokrasi maupun legislatif) sering melakukan langkah pengambilan dan pelaksanaan kebijakan politik yang tidak selaras dengan aspirasi kolektif masyarakat sipil. Lembaga kekuasaan politik lokal yang sebagian besar didominasi kalangan partai politik peraih suara Pemilu yang lalu seringkali tidak mampu menjalankan fungsi keterwakilan politik dan kurang optimal dalam peran sebagai pelayan aspirasi publik.

Partisipasi politik rakyat adalah keterlibatan rakyat secara perseorangan (privat citizen) untuk mengerti, menyadari, mengkaji, memelobi dan memprotes suatu kebijakan yang ditelurkan oleh pemerntah dengan tujuan mempengaruhi kebijakan agar aspirasi terhadap kepentingan mereka. Dari ilustrasi di atas, partisipasi rakyat bisa dipahami sebagai keterlibatan rakyat dalam pengertian politik secara sempit-hubungan Negara dan masyarakat (dalam bingkai governance)-dan juga politik secara luassemua bentuk keterlibatan masyarakat dalam proses berhimpun untuk mempengaruhi ataupun melakukan perubahan terbadap keputusan yang diambil partisipasi politik rakyat sebetulnya adalah tema sentral dan proses demokratisasi Dalam kerangka inilah masyarakat bisa berperan sebagai subyek dalam menentukan arah masa depan society-nya.

Partisipasi pemilih merupakan salah satu aspek penting demokrasi. Partisipasi pemilih merupakan taraf partisipasi politik warga 
masyarakat dalam kegiatan-kegiatan politik baik yang bersifat aktif maupun pasif dan bersifat langsung maupun yang bersifat tidak langsung guna mempengaruhi kebijakan pemerintah partisipasi politik sebagai By political participation we mean activity by private citizens designed to influence government decision-making. Participation may be individual or collective, organized or spontaneous, sustained or sporadic, peaceful or violent, legal or illegal, effective or ineffective.

Partisipasi politik dapat dibedakan dalam dua hal. Pertama, partisipasi dalam warga masyarat dalam keadaan sadar dalam hal untuk memperjuangkan hak otonom masyarakat yang tanpa didorong oleh kekuataan diluar diri individu atau partisipasi politik tidak berdasarkan mobilisasi yang dilakoni baik oleh aktor maupun pemerintah. Kedua, partisipasi politik yang dimobilisasi atau digerakan oleh aktor-aktor politik, sehingganya partisipasi politik lebih bersifat semu bukan berpartisipasi dalam keadaan sadar.

Keputusan politik menyangkut dan mempengaruhi kehidupan warga masyarakat maka warga masyarakat berhak mempengaruhi proses pembuatan dan pelaksanaan keputusan. Maka partisipasi berarti keikutsertaan warga negara biasa atau yang tidak mempunyai kewenangan dalam mempengaruhi proses pembuatan dan pelaksanaan keputusan politik.

Partisipasi politik yang meluas merupakan ciri khas modernisasi politik. Istilah partisipasi politik telah digunakan dalam berbagai pengertian yang berkaitan dengan perilaku, sikap dan persepsi yang merupakan syarat mutlak bagi partisipasi politik. Di Indonesia perdebatan tentang partisipasi politik hanya terbatas pada angka tingkat partisipasi masyarakat dalam setiap pemilihan umum. Sebelum reformasi bergulir, angka itu selalu berada pada kisaran 90 persen, maka dengan mudah orang akan menyebut bahwa partisipasi politik masyarakat tinggi. Tapi sebetulnya bukan itu, atau tepatnya bukan satu-satunya ukuran tentang tingginya tingkat partisipasi masyarakat dalam pemilihan umum. Yang Iebih penting adalah adanya jaminan dan mekanisme yang baku, dan comfortable bagi semua rakyat untuk dapat menyalurkan pikiran-pikirannya kedalam sebuah institusi formal. Satu peran rakyat yang amat penting adalah melakukan social control terhadap pemerintah, maupun institusi-insitusi lain seperta DPR ataupun peradilan. Secara kasat mata mungkin bisa kita mengatakan bahwa partisipasi politik masyarakat akhir-akhir ini meningkat. Intensitas demo yang makin marak, interaktif TV dan radio yang makin mendominasi program-program massa, serta meningkatnya keterlibatan publik dalam perdebatan tentang satu wacana tertentu.

Hubungan antara pemerintahan (state) dengan warga negara/rakyat (society) selalu berada dalam bingkai interaksi politik diantara keduanya dalam wujud organisasi negara. Hubungan state and society ini dapat tergambarkan dalam icon yang diberi label demokrasi. Sejak lama, sebagai gambaran besar, demokrasi menjadi cara terbaik dalam perkembangan organisasi negara modern. Demokrasi yang dimaksud merupakan instrumen universal, namun juga memiliki karakteristik ideografis dalam hal-hal tertentu. Misalnya kita akan menemukan adanya demokrasi liberalis, demokrasi sosialis dan bahkan demokrasi Pancasila. Sementara dalam hirarkhi suatu negara jangkauan pengaruh, kita bisa merujuk pada dua jenis atau kelompok demokrasi, yaitu demokrasi dalam lingkup negara dan demokrasi lokal. Tulisan ini bermaksud mendeskripsikan demokrasi dalam tataran lokal pada ranah ideografis Indonesia dengan memfokuskan diri pada fenomena pemilihan kepala daerah secara langsung di Kabupaten Sintang Provinsi Kalimantan Barat.

Desentralisasi merupakan salah satu asas dalam penyelenggaraan pemerintahan yang bertujuan untuk sharing power dalam penyelenggaraan pemerintahan yang dekat dengan rakyatnya. Sementara itu, Cornelis Lay (2003) menyatakan bahwa dengan desentralisasi pengaturan politik dan pemerintahan yang stabil dapat dilakukan. Dengan desentralisasi dapat diakomodasi sharing of power, sharing of revenue, dan penguatan lokalitas, selain pengakuan dan penghormatan terhadap identitas daerah. Berkaitan dengan sharing of power maka pemberian desentralisasi secara devolusi menjadi penting. Apalagi dalam era reformasi ini yang akan memunculkan pemilu lokal bagi elit ekesekutif secara langsung tentunya akan terjadi penguatan dalam sistem pemerintahan daerah.

Desentralisasi merupakan bentuk hubungan antara pemerintah pusat dan pemerintahan daerah yang pada umumnya memiliki dua bentuk yaitu: Devolusi dan dekonsentrasi. Dalam ideografis Indonesia kita pernah mengenal asas tugas pembantuan atau medebewind sebagai bagian dari desentralisasi. Berdasarkan ranah politik pemerintahan maka desentralisasi yang berkaitan dengan otonomi penyelengaraan pemerintahan di daerah adalah devolusi. Sementara dekonsentrasi masih merupakan kepanjangan tangan kebijakan pusat di daerah. 
Berdasarkan asas desentralisasi hubungan rakyat dan pemerintahan daerah berada dalam koridor demokrasi daerah. Pelibatan pemerintahan daerah dalam mengurus kewenangannya merupakan keleleuasaan yang bertujuan untuk pengembangkan demokrasi daerah dan pembangunan daerah yang pada gilirannya mengarah pada kesejahteraan rakyat di wilayah kerja daerahnya.

\section{METODE PENELITIAN}

Penelitian tentang Partisipasi Politik Masyarakat Dalam Pemungutan Suara Pemilihan Bupati dan Wakil Bupati Sintang Tahun 2020 Dalam Kondisi Bencana Non Alam Carona Virus Disease 2019 (COVID 19) menggunakan rancangan penelitian kualitatif. Pendekatan kualitatif mengarah pada metode penelitian deskriptif, dimana data yang dikumpulkan berupa kata-kata, gambar, dan angka. Pendekatan kualitatif diarahkan pada latar dan individu secara utuh, dan mempunyai prosedur penelitian yang menghasilkan data deskriptif. Penelitian yang akan dilakukan oleh peneliti memakai penelitian kualitatif, menggunakan manusia sebagai alat pengumpulan data utama. Pada waktu pengumpulan data kehadiran peneliti di lapangan sangat penting dalam menunjang pengumpulan data yang valid. Penelitian dilakukan di Kabupaten Sintang Provinsi Kalimantan Barat, Sumber data dalam penelitian ini adalah Anggota KPUD, Anggota tim sukses, Pemerintah Daerah, Tokoh Masyarakat, dan Masyarakat. Sumber data utama dalam penelitian kualitatif ialah kata-kata dan tindakan, selebihnya adalah data tambahan seperti dokumen dan lainlain yaitu sember data primer dan sumber data sekunder. Analisa data dilakukan oleh peneliti sepanjang penelitian dapat dilakukan oleh peneliti sepanjang penelitian dilakukan secara terus menerus dari awal sampai akhir penelitian. Dalam proses analisa data peneliti menggunakan langkahlangkah : (1) reduksi data (data reduction), (2) penyajian data (display data), dan (3) kesimpulan (conclution drawing verification).

Penelitian kualitatif dianggap lebih sesuai untuk memperoleh gambaran dan informasi mengenai persepsi, sikap serta pengalaman penyelenggara pemilu dalam memahami isu-isu yang berkaitan dengan partisipasi politik masyarakat yang berhubungan dengan pemungutan suara dalam pemilihan bupati dan wakil bupati. Dalam hal ini, melalui pendekatan kualitatif diharapkan informasi yang lebih luas dan detail tentang partisipasi politik masyarakat dalam pemilihan bupati dan wakil bupati.

\section{HASIL DAN PEMBAHASAN}

\section{Pemilihan Bupati dan Wakil Bupati Dalam Kondisi Bencana Non Alam COVID-19}

Demokrasi sebagai aspek penting berkaitan dengan pemerintahan dengan hirarkhi kekuasaan yang terdapat dalam suatu sistem politik negara. Artinya, akan terdapat sistem politik nasional yang didalamnya terdapat sub sistem politik daerah dalam bingkai sistem negara yang dianutnya. Pemilahan demokrasi lokal ini bukan berarti terdapat determinasi wilayah pemberlakuan demokrasi atau bahkan terdapat perbedaan demokrasi dari induknya. Dalam tulisan ini demokrasi lokal ditujukan sebagai bagian utuh dari demokrasi di Indonesia dalam pelaksanaan rekrutmen elit politik di pemerintahan daerah.

Demokrasi lokal merupakan bagian dari subsistem politik suatu negara yang derajat pengaruhnya berada dalam koridor pemerintahan daerah. Di Indonesia Demokrasi lokal merupakan subsistem dari demokrasi yang memberikan peluang bagi pemerintahan daerah dalam mengembangkan kehidupan hubungan pemerintahan daerah dengan rakyat di lingkungannya.

Dari sisi kedaulatan rakyat daerah, demokrasi lokal dibangun untuk memberikan porsi yang seharusnya diperoleh rakyat lokal dalam pemberian legitimasi pada elit eksekutifnya. Selama ini rakyat daerah memberikan kedaulatan hanya pada legislatif daerah saja-melalui pemilu legislatif. Maka merujuk pada konsep trias politica-nya Montesquieu pemisahan kekuasaan atas tiga lembaga negara untuk konteks pemerintahan daerah terletak pada lembaga eksekutif dan legislatif daerah, sedangkan dalam kerangka yudikatif menginduk pada kelembagan pusat. Hal ini terkait dengan pola hubungan pemerintahan pusat daerah dalam asas desentralisasi. Kedaulatan rakyat dalam kerangka sistem pemerintahan dapat dibagi kedalam hirarkhi demokrasi nasional dan lokal dari tata cara rekrutmen politiknya.

Ketidakpercayaan rakyat dan era reformasi mendorong adanya pilkada langsung. Hal ini tidak langsung berkatan dengan baik atau tidaknya demokrasi, karena di negara lain uga terdapat variasi pelaksanaan demokrasi baik yang langsung, perwakilan bahkan dengan appointment. Derajat kepentingannya adalah terpilihnya pejabata politik yang akuntabel sesuai dengan needs for achievment rakyatnya. 
Salah satu faktor pendukung Pilkada adalah tingkat partispasi masyarakat, jumlah partisipasi yang banyak akan menunjukkan kesadaran masyarakat tentang pentingnya Pilkada. Meskipun jika pada akhirnya tingkat partisipasi masyarakat rendah tidak dapat membatalkan hasil Pilkada, namun hal ini dapat menunjukkan kesadaran politik masyarakat dalam memposisikan dirinya sebagai unsur sentral suatu daerah.

Partisipasi yang lemah berakibat pada sebuah realitas politik yang kini menggejala di permukaan dan terkait dengan era otonomi daerah yaitu terjadinya kesenjangan politik antara masyarakat sipil dengan lembaga kekuasaan lokal, diman. faktor pelaksana kekuasaan lokal sering melakukan langkah pengambilan dan pelaksanaan kebijakan politik yang tidak selaras dengan aspirasi kolektif masyarakat sipil.

Kabupaten Sintang merupakan salah satu kabupaten yang ikut melaksanakan pilkada yaitu pemilihan Bupati dan Wakil Bupati pada tahun 2020. Hasil penelitian menunjukan bahwa serangkaian tahapan pemilihan Bupati dan Wakil Bupati Sintang Tahun 2020 mulai dari tahapan persiapan seperti perencanaan program dan anggaran; penyusunan peraturan penyelenggaraan pemilihan; perencanaan penyelenggaraan meliputi penetapan tata cara dan dan jadwal pelaksanaan pemilihan; pembentukan PPK, PPS dan KPPS; Panwas Kecamatan, PPL, dan Pengawas TPS; pemberitahuan dan pendaftaran pemantau pemilihan; dan penyerahan daftar penduduk potensial pemilih. Serta tahapan penyelenggaraan yang meliputi pendaftaran bakal calon; uji publik; pengumuman pendaftaran calon; pendaftaran calon; penelitian persaratan calon; penetapan calon; pelaksanaan kompanye; pelaksanaan pemungutan suara; perhitungan suara dan rekapitulasi perhitungan suara; dan penetapan calon terpilih. Serangkaian tahapan persiapan dan penyenggaraan berjalan dengan baik sesuai dengan yang direncanakan.

Pemilihan Bupati dan Wakil Bupati Sintang pada tahun 2020 di ikuti 3 pasangan calon yaitu calon nomor urut 1: dr. H. Jarot Winarno, M.Med.P.H. dan Sudiyanto, S.H.; calon nomor urut 2: Drs. Askiman, M.M dan Drs. Hatta, M.Si.; calon nomur urut 3: Yohanes Rumpak, S.Pd.M.M dan Syarifuddin, M.M. Pasangan calon Pemilihan Bupati dan wakil Bupati Sintang tahun 2020 semuanya berasal dari usulan gabungan partai politik dan tidak ada pasangan melalui jalur perorangan (independen). Pelaksanaan pemungutan suara dilaksanakan serempak di 14 Kecamatan di
Kabupaten Sintang pada tanggal 9 Desember 2020 dan pasangan calon nomor urut 1: dr. H. Jarot Winarno, M.Med.P.H. dan Sudiyanto, S.H. memperoleh suara terbanyak sebesar 144.529 suara.

Penyelenggaraan pemungutan suara dalam Pemilihan Bupati dan Wakil Bupati Sintang dilakukan dengan menerapkan protocol kesehatan pencegahan dan pengendalian Carona Virus Disease 2019 sebagai berikut: 1) anggota KPPS dan petugas ketertiban TPS menggunakan alat pelindung diri berupa masker, sarung tangan, pelindung wajah (face shield); 2) pemilih yang hadir menggunakan masker; 3) KPPS menyediakan sarung tangan untuk digunakan oleh pemilih; 4) saksi dan pengawas TPS yang hadir di TPS menggunakan masker dan sarung tangan; 5) menjaga jarak paling kurang 1 (satu) meter antar semua pihak yang terlibat; 6) tidak melakukan jabat tangan dan kontak fisik lainnya; 7) menyediakan sarana sanitasi yang memadai meliputi fasilitas cuci tangan dengan air yang mengalir dan sabun serta disinfektan; 8) mengatur pembatasan jumlah pemilih yang memasuki TPS; 9. wajib menggunakan alat tulis masing-masing; 10) melakukan rapit tes dan pemeriksaan kesehatan kepada anggota KPPS; dan 11) melakukan pengecekan kondisi suhu tubuh anggota KPPS, petugas ketertiban TPS, pemilih, saksi, dan pengawas TPS yang hadir di TPS.

Proses pemberian suara pada pemilihan Bupati dan Wakil Bupati Sintang dilakukan dengan menerapkan protocol kesehatan pencegahan dan pengendalian Carona Virus Disease 2019 sebagai berikut; 1). pemilih menggunakan sarung tangan untuk mencoblos dengan paku yang sudah disediakan; 2) anggota KPPS melakukan sterilisasi paku secara berkala dengan disinfektan; 3) pemilih yang telah selesai memberikan suara membuang sarung tangan pada tempat pembuangan yang telah disediakan di TPS; 4) pemilih yang telah memberikan suaranya diberikan tanda khusus berupa tinta yang diteteskan kesalah satu jari pemilih; 5) pemilih yang telah selesai memberikan suara segera meninggalkan area TPS dan tidak berkerumun di lingkungan TPS.

Pemilih yang memiliki suhu tubuh 37,3Ú (tiga puluh tujuh koma tiga derajat) celcius atau lebih, dilakukan hal-hal sebagai berikut: a) pemilih yang bersangkutan diarahkan ke tempat yang disediakan di luar TPS; b) pemilih yang bersangkutan mengisi daftar hadir yang diberikan oleh anggota KPPS; c) pemilih menerima surat suara dan sarung tangan dari anggota KPPS; d) pemilih memberikan hak pilihnya dengan 
didampingi orang lain yang dipercaya pemilih atau dibantu anggota KPPS dan mengisi formulir pernyataan pendamping pemilih; e) pemberian suara dilakukan di bilik suara yang tetap menjamin pemberian suara berlangsung sesuai dengan ketentuan perundang-undangan; dan f) setelah memberikan suara, pemilih diberikan tanda berupa tinta di salah satu jari pemilih.

\section{Partisipasi Politik Masyarakat}

Pesta demokrasi, apapun bentuknya, tentu berangkat dari spektrum demokrasi. Pesta ini selalu diawali dengan niatan hendak memenuhi tuntutan demokrasi. Pesta ini dijalankan berdasarkan proses-proses dan nilai-nilai demokrasi. Pesta ini juga diharapkan bisa melahirkan sebuah hasil yang sejalan dan sesuai dengan kriteria demokrasi. Dengan demikian pemilukades, pemilukada, pilpres dan pemilu legislatif adalah pesta-pesta yang dijalankan untuk dan atas demokrasi.

Semuanya hanya merupakan sarana hanya menuju demokrasi dan bukanlah sekedar bertujuan untuk memilih dan melegimitasi pemimpin dan wakil-wakilnya. Lebih dari itu, untuk mengupayakan bagaimana agar nilai-nilai demokrasi dapat tumbuh subur dan berkontribusi positif bagi peningkatan kesejahteraan rakyat.

Ketika telah lahir kepuasan bersama yang didukung suara mayoritas dan diasumsikan sebagai keputusan terbaik, maka menjadi kewajiban bagi setiap individu yang berbeda pendapat dan sikap itu untuk menghargai dan mendukung keputusan tersebut.

Pilkada langsung yang akan diselenggrakan tahun 2020 ini, tidak akan terlepas dari pentingnya partisipasi politik rakyat. Kalaupun tidak ada batasan yang jelas bahwa jumlah pemilih yang menggunakan haknya secara sah sebagai indikator keberhasilan pemilu tersebut, namun kita bisa melihat derajat partispasi politik sebagai respon atas pentingnya rekrutmen politik elit daerah.

Banyak batasan yang diberikan oleh ahliahli politik dalam literatur-literaturnya. Salah satu definisi Partisipasi politik yang berkaitan dengan pilkada langsung ini dapat dilihat dari pendapatnya Miriam Budiardjo (1994) yang menayatakan bahwa "Kegiatan individu atau kelompok secara aktif dalam kehidupan politik, memilih pimpinan negara dan terlibat dalam mempengaruhi kebijakan publik" sebagai batasan dari partisipasi politik.
Hal senada juga diungkapakan oleh Herbert McClosky yang dikutip oleh Budiardjo (1994) yang berkaitan dengan sifat sukarela dan proses pemilihan penguasa.

Keterlibatan secara sukarela dalam pemilihan bupati dan wakil bupati merupakan indikator positif atau negatifnya rakyat daerah sebagai warga yang mempunyai hak politik sebagai voter. Tentu saja rakyat sebagai waraga negara agar dapat berperan aktif dalam partisipasi politik perlu terpaan pendidikan politik dari berbagai agennya. Tanpa terpaan itu maka sukar untuk mendapatkan kadar partispasi politik yang baik dalam kerangka demokrasi.

Bentuk partispasi politik rakyat daerah dalam pemilihan bupati dan wakil Bupati langsung ini dapat dilihat dari berbagai bentuknya, mulai dari sebagai orang atau kelompok yang apolitis, pengamat, maupun partisipan Seperti pada dua pemilu yang lalu maka akan ada prosentasi rakyat yang apolitis dalam arti mereka yang termasuk tak acuh dalam kegiatan dan proses politik. Sementara bentuk pengamat merupakan porsi yang paling banyak, yaitu mereka yang melakukan pengaruh dalam proses politik sebatas sebagai anggota organsisasi, hadir dalam kampanye, dan voter. Sementara dalam bentuk partisipan, diantaranya rakyat terlibat sebagai aktivis partai, dan kelompok kepentingan. Sebagai aktivis, pertisipasi politik rakyat sudah mengarah pada derajat menduduki jabatan-jabatan organisasi/ politik.

Sifat sukarela dan terlibat dalam rekrutmen politik serta mempengaruhi kebijakan publik merupakan warna proses politik yang dapat digambarkan dalam pemilu legisltaif dan pemilu presiden secara langsung pada tahun 2019 yang lalu. Hal ini tidak terlepas dari pengalaman praktis rakyat dalam pemilu langsung tadi. Dengan tata cara dan tahapan yang relatif sama dengan pemilu presiden diperkirakan partisipasi politiknya juga tidak jauh berbeda. Namun demikian untuk menghindari antiklimaks dari partisipasi politik masyarakat maka perlu media sosialisasi politik termasuk di dalamnya pendidikan politik yang memadai sehingga rakyat daerah akan merespon dalam bentuk pertisipasi politik yang memadai baik dari sudut pandang kualitas mapun kuantitasnya.

Partisipasi masyarakat Kabupaten Sintang dalam Pemilihan Bupati dan Wakil Bupati Sintang tahun 2020 dapat terlihat dari daftar pemilih yang 
terdaftar dalam daftar pemilih tetap sebesar 289.554 dan yang menggunakan hak pilihnya sebesar $238.843(82,49 \%)$, sehingga $50.711(17,51 \%)$ pemilih yang tidak menggunakan hak pilihnya. Apabila dilihat dari data pemilih, jumlah pemilih adalah sebesar 293.942 dan yang menggunakan hak pilih sebesar $243.231(82,75 \%)$, sehingga 50,711 $(17,25 \%)$ pemilih yang tidak menggunakan hak pilihnya.

Partisipasi politik masyarakat dalam Pemilihan Bupati dan Wakil Bupati Sintang tahun 2020 meningkat dari Pemilihan Bupati dan Wakil Bupati Pada Tahun 2015 sebesar 75,42 \% menjadi $82,75 \%$ dan melebihi target secara nasional sebesar 77,5\% dengan kodisi pemilihan kepala daerah serantak lanjutan dalam kondisi Bencana Non Alam Carona Virus Disease 2019 (COVID 19).

Dari hasil temuan penelitian faktor-faktor yang mempengaruhi partisipasi politik masyarakat pada Pemilihan Bupati dan Wakil Bupati Sintang pada tahun 2020 adalah (1). Faktor Perangsang Politik (2). Faktor Karakteristik Pribadi (3). Faktor Karakteristik Sosial (4). Faktor Keadaan Politik. Pelaksanaan Partisipasi politik masyarakat tentu saja tidak berlangsung tanpa adanya faktor - faktor pendukung, tentu saja banyak hal yang sangat mempengaruhi pelaksanaan partisipasi politik masyarakat.

Peran partai politik sebagai penyandang fungsi sosialisasi, pendidikan, partisipasi dan rekrutmen politik merupakan media yang sangat efektif dalam memicu partisipasi politik rakyat daerah. Disamping itu, peran KPU kabupaten dalam sosialisasi tahapan pilkada langsung juga berpengaruh pada tingkat partisipasi politik dalam pemilihan bupati dan wakil bupati langsung ini. Terpaan pendidikan politik dari berbagai agenda dalam pemilihan bupati dan wakil bupati yang dilakukan dengan baik akan berdampak pada kontribusi partisipasi politik yang baik pula. Peran partai politik yang melakukan penjaringan pasangan calon dengan obyektif dan sesuai dengan kebutuhan rakyat dalam menentukan pempinan politik daerah, akan menarik minat rakyat daerah untuk berperan serta.

\section{KESIMPULAN DAN SARAN}

Berdasarkan pembahasan yang telah dikemukakan diatas, maka penelitian ini dapat disimpulkan Pelaksanaan pemilihan Bupati dan Wakil Bupati Sintang Tahun 2020 sudah sesuai dan mengikuti Peraturan Komisi Pemilihan Umum Nomor 6 Tahun 2020, dirubah dengan Peraturan Komosi Pemilihan Umum Nomor 10 Tahun 2020 dan Perubahan kedua Peraturan Komisi Pemilihan Umum Nomor 13 Tahun 2020 Tentang Pelaksanaan Pemilihan Gubernur dan Wakil Gubernur, Bupati dan wakil Bupati, dan/atau Wali Kota dan Wakil Wali Kota Serentak Lanjutan Dalam Kondisi Bencana Non Alam Carona Virus Disease 2019 (COVID-19).

Partisipasi politik masyarakat dalam pemilihan Bupati dan Wakil Bupati Kabupaten Sintang Tahun 2020 sebesar $82,75 \%$ hal ini menandakan semakin baiknya partisipasi politik masyarakat dalam proses demokrasi di Kabupaten Sintang. Faktor-Faktor yang mempengaruhi partisipasi politik masyarakat dalam pemilihan Bupati dan Wakil Bupati Sintang Tahun 2020 adalah perangsang politik, karakteristik pribadi, karekteristik sosial dan keadaan politik.

Diharapkan pemerintah pusat maupun pemerintah daerah memberikan ransangan atau stimulus baik dana, kelembagaan, pelatihan, dan sosialisasi tentang pentingnya partisipasi politik masyarakat terutama pemilih pemula, sehingga masyarakat tidak menjadi malas dan ragu ragu dalam menggunakan hak politiknya. Perlu adanya kerjasama yang baik antara pemerintah daerah, penyelenggara pemilu, partai politik untuk melakukan kegiatan-kegiatan yang dapat menumbuhkan partisipasi politik masyarakat.

\section{DAFTAR PUSTAKA}

Amirudin dan A. Zaini Bisri, 2006. Pilkada Langsung Problem dan Prospek, Pustaka Pelajar, Yogyakarta 
Atip Tartiana, 2010. Tahun Pemilukada 2010, artikel dalam Pikiran Rakyat, 5 Januari 2010

Budiardjo, Miriam, 1994, Demokrasi di Indonesia: Demokrasi Parlementer dan Demokrasi Pancasila, PT Gramedia Pustaka Utama, Jakarta

Faturohman, Deden dan Wawan Sobari, 2002, Pengantar Ilmu Politik, UMM Press, Malang.

Hendri Zainudin, 2907. Pemilukada dan Kedewasaan Berdemokrasi, Berita Pagi, Rabu 12 Desember 2007

Irvan Mawardi, 2008. Pilkada dan Partisipasi Politik, artikel dalam www. jppr.org

Lay, Cornelis,2003, "Otnomi Daerah dan KeIndonesiaan" dalam Abdul Gaffar Karim (ed.), Kompleksitas Persoalan Otonomi di Indonesia, Pustaka Pelajar, Yogyakarta.

Pratikno, 2003, Pilihan yang Tidak Pernah Final, Dalam Abdul Gaffar Karim (Ed.), Desentralisasi, , Kompleksitas Persoalan Otnomi Daerah di Indonesia, Pustaka Pelajar, Yogyakarta.

Riyadmaji, Dodi, 2003, Mengkritisi Pemikiran Pemilihan Kepala Daerah Secara Langsung, dalam Abdul Gaffar Karim (ed.), Kompleksitas Persoalan Otonomi di Indonesia, Pustaka Pelajar, Yogyakarta.

Sinaga, Kastorius, 2003, Pemilihan Kepala Daerah Langsung Kota dan Kabupaten: Beberapa catatan Awal, dalam Abdul Gaffar Karim (ed.), Kompleksitas Persoalan Otonomi di Indonesia, Pustaka Pelajar, Yogyakarta

Sjafii, Inu Kencana, 1994, Pengantar Ilmu Pemerintahan, CV. Mandar Madju, Bandung.

Tim Pustaka Kendi, 2004, Desentralisasi dalam Prakrtek, tejemahan dari Henry Maddick,1961, Democracy, Decentralisation and Development.
Tricahyo,Ibnu, 2005, Undang-Undang 32 dan 33 tahun 2004. Pilkada Langsung, dalam Pelatihan DPRD Kabupaten Malang tanggal 18 dan 19 Januari 2005 di Batu.

Utomo, Tri Widodo W.,2004, Pilkada Langsung dalam Kerangka Reformasi Birokrasi: Beberapa Catatan Kritis, dalam Inovasi Online, vol.2/XVI/Nov.2004

\section{Peraturan Perundang-Undangan:}

Peraturan Komisi Pemilihan Umum Republik Indonesia Nomor 6 Tahun 2020 Tentang Pelaksanaan Pemilihan Gubernur dan Wakil Gubernur, Bupati dan Wakil Bupati, dan/atau Wali Kota dan Wakil Wali Kota Serentak Lanjutan Dalam Kondisi Bencana Non Alam Carona Virus Disease 2019 (COVID-19)

Peraturan Komisi Pemilihan Umum Republik Indonesia Nomor 10 Tahun 2020 Tentang Perubahan Atas Peraturan Komisi Pemilihan Umum Nomor 6 Tahun 2020 Tentang Pelaksanaan Pemilihan Gubernur dan Wakil Gubernur, Bupati dan Wakil Bupati, dan/atau Wali Kota dan Wakil Wali Kota Serentak Lanjutan Dalam Kondisi Bencana Non Alam Carona Virus Disease 2019 (COVID-19)

Peraturan Komisi Pemilihan Umum Republik Indonesia Nomor 13 Tahun 2020 Tentang Perubahan Kedua Atas Peraturan Komisi Pemilihan Umum Nomor 6 Tahun 2020 Tentang Pelaksanaan Pemilihan Gubernur dan Wakil Gubernur, Bupati dan Wakil Bupati, dan/atau Wali Kota dan Wakil Wali Kota Serentak Lanjutan Dalam Kondisi Bencana Non Alam Carona Virus Disease 2019 (COVID-19).

Keputusan Komisi Pemilihan Umum Kabupaten Sintang Nomor: 1244/PL.02.6-Kpt/6105/ KPU-Kab/XII/2020 Tentang Penetapan Rekapitulasi Hasil Penghitungan Suara Pemilihan Bupati dan Wakil Bupati Sintang Tahun 2020. 